\title{
Variation of Quantitative Anatomical Characteristics in the Culm of Belangke Bamboo (Gigantochloa pruriens)
}

\begin{abstract}
Atmawi Darwis, ${ }^{a}$ Apri Heri Iswanto,,$*$ Woo-Seok Jeon, ${ }^{\mathrm{c}}$ Nam-Hun Kim, ${ }^{\mathrm{d}, *}$ Basuki Wirjosentono, ${ }^{\mathrm{e}}$ Arida Susilowati, ${ }^{\mathrm{f}}$ and Rudi Hartono ${ }^{\mathrm{b}}$

The anatomical characteristics of the stem of belangke bamboo (Gigantochloa pruriens), which is native in North Sumatra, Indonesia, were examined to attain valuable information for identification and effective utilization. The number and type of vessel bundles and the fiber and metaxylem dimensions in the longitudinal (bottom, middle, and top) and radial (outer, central, and inner) directions of the bamboo culm were investigated by optical microscopy. The vascular bundles were distributed unevenly and arranged alternately, as shown by cross-sectional images of the culms. The proportion of vascular bundles in the culm decreased from the outer layer to the inner layer and tended to increase from the bottom to the top. Most vascular bundles were classified as type IV at the bottom and as type III in the middle and top parts. Fiber length and cell wall thickness tended to increase from the bottom to the top and from the inner layer to the outer layer. Metaxylem length and diameter increased from the outer layer to the inner layer and from the bottom towards the top of the stem. It was revealed that the anatomical characteristics of the belangke bamboo varied significantly in the vertical and radial directions.
\end{abstract}

Keywords: Belangke bamboo; Gigantochloa pruriens; Vascular bundles; Fibers; Metaxylem

Contact information: a: School of Life Sciences and Technology, Institut Teknologi Bandung, Gedung Labtex XI, Jalan Ganesha 10, Bandung 40132, West Java, Indonesia; b: Department of Forest Product, Faculty of Forestry, Universitas Sumatera Utara, Padang Bulan, Medan 20155, Indonesia; c: Department of Forest Products, National Institute of Forest Science, 57 Heogi-ro, Dongdaemun-gu, Seoul, 02455, Republic of Korea; d: College of Forest and Environmental Sciences, Kangwon National University, 24341, Chuncheon, Korea; e: Department of Chemistry, Faculty of Mathematics and Natural Sciences, Universitas Sumatera Utara, Padang Bulan, Medan 20155, Indonesia; f: Department of Sylviculture, Faculty of Forestry, Universitas Sumatera Utara, Padang Bulan, Medan 20155, Indonesia;

*Corresponding authors: Apri Heri Iswanto(apri@usu.ac.id); Nam-Hun Kim(kimnh@kangwon.ac.kr)

\section{INTRODUCTION}

Bamboos grow in the tropical, subtropical, and temperate regions of all continents except Europe and western Asia (Dransfield and Widjaja 1995). Bamboos, commonly grown as woody bamboos, belong to the family Gramineae, and form the tribe Bambuseae of the subfamily Bambusoideae. Bamboo culms are cylindrical, hollow, and tapered towards the top. The diameter of the bamboo culm decreases from the bottom to the top, which causes the thickness of the stem wall to decrease (Zakikhani et al. 2017; Darwis and Iswanto 2018; Darwis et al. 2018)

Anatomically, the bamboo culm is composed of vascular bundles and parenchymatous tissue (Liese 1987a). Vascular bundles in bamboo stems are composed of one or two protoxylems, two large metaxylem vessels, and thin-walled phloem consisting of sieve tubes connected to companion cells. Metaxylem and phloem tissues are surrounded by sclerenchymatous fibers. Vascular bundles in bamboo stems play an important role in supporting bamboo strength and channels (Liese 1987b). These components in bamboo 
culms vary in the radial and axial directions. Moreover, the properties of bamboo vary in a bamboo culm, between bamboo species, and in the radial and axial directions (Liese 1998; Jeon et al. 2018).

There are currently as many as 143 bamboo species in Indonesia (Widjaja 2001). The genera Bambusa, Dendrocalamus, and Gigantochloa are the most common and utilized. One of the endemic bamboo species from the Gigantochloa genus found in Indonesia is Gigantochloa pruriens. This species is found in North Sumatra and Southeast Aceh in Indonesia, and it is known as buluh belangke, buluh regen, and buluh yakyak. The culms are valuable materials for construction, including for pillars, walls, roofing, and also for making the Batak traditional calendar, while young culms are used for cooking glutinous rice (Widjaja 1987).

To date, there is little information on the belangke bamboo species, especially related to the anatomical characteristics of the stem. Therefore, this study examined the variation of quantitative anatomical properties in the axial and radial directions of belangke bamboo culms. This research can provide valuable fundamental knowledge for species identification and effective utilization.

\section{EXPERIMENTAL}

\section{Materials}

The culms of 2-year-old belangke bamboo (Gigantochloa pruriens) were obtained from the Binjai area of North Sumatra, Indonesia ( $\left.03^{\circ} 31^{\prime} 40^{\prime \prime} \mathrm{N}, 98^{\circ} 27^{\prime} 03^{\prime \prime} \mathrm{E}\right)$. The length and diameter of the bamboo for this study were approximately $14 \mathrm{~m}$ and $6 \mathrm{~cm}$, respectively. The bottom, middle, and top parts of the bamboo stem were examined.

\section{Sample Preparation}

Samples from each sub-section were soaked in water for $24 \mathrm{~h}$ until softening, and thin cross-sectional slides with a thickness of $20 \mu \mathrm{m}$ to $30 \mu \mathrm{m}$ were obtained using a microtome. The thin slices were stained in 1\% safranin solution for $5 \mathrm{~min}$ and then rinsed with an ethanol series $(30 \%, 50 \%, 70 \%, 90 \%$, and 99.5\%). The slices were soaked consecutively with carboxylol and toluene, and the permanent slides were prepared with Canada balsam resin for microscopy. Maceration was carried out according to the Franklin method (1945). Match-sized wood pieces were put into a mixed solution of glacial $\mathrm{H}_{2} \mathrm{O}_{2}$ and $\mathrm{CH}_{3} \mathrm{COOH}$ with a ratio of $1: 1(\mathrm{v} / \mathrm{v})$ and then heated at $60{ }^{\circ} \mathrm{C}$ until defibrillation. The defibrillated samples were rinsed with distilled water, stained with safranin-O coloring, and dehydrated with ethanol. The permanent slides were obtained using Canada balsam resin.

\section{Measurements of Vascular Bundle Characteristics and Cell Dimensions}

Microscopic observations were made from the outer layer to the inner layer of the bamboo culm, as shown in Fig. 1(A). The frequency and radial (RD) and tangential (TD) diameters of the vascular bundles in the cross section of the bamboo culm were measured. The proportion of vascular bundles and parenchymatous tissue was determined for the outer, middle, and inner parts at each height of the bamboo culm. Data were collected up to 4 times. The macroscopic characteristics of the bamboo culm were observed using a Nikon SMZ745T stereomicroscope (Nikon Corporation, Tokyo, Japan), while microscopic characteristics were observed using an optical microscope (Nikon ECLIPSE E200LED 
MV RS, Nikon Corporation, Tokyo, Japan). Measurements for the fiber and vessel dimensions were performed with 30 replications. Anatomical characteristics from the optical micrographs were analyzed using NIS-Elements v. 4.00.00 imaging software (Nikon Corporation, Tokyo, Japan).

\section{Statistical Analysis}

This study was conducted using a factorial completely randomized design (CRD) with two treatments, where factor A was the longitudinal part (bottom, middle, and top), and factor B was the radial part (outer, center, and inner). Sample data were analyzed using IBM SPSS Statistics 19 software (IBM, Armonk, NY, USA) at $\mathrm{p}<0.05$.

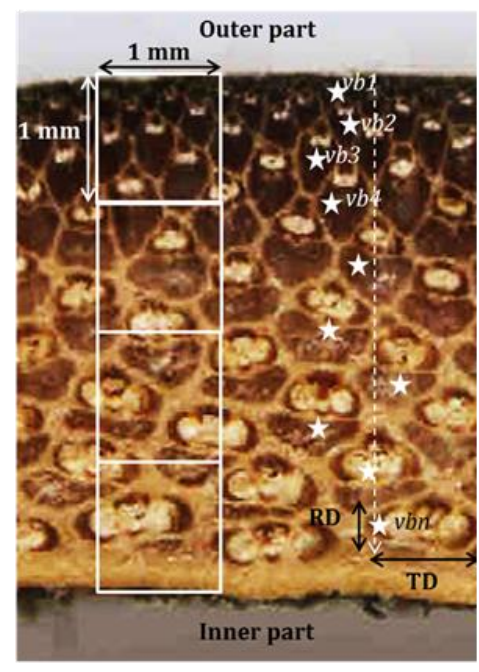

(A)

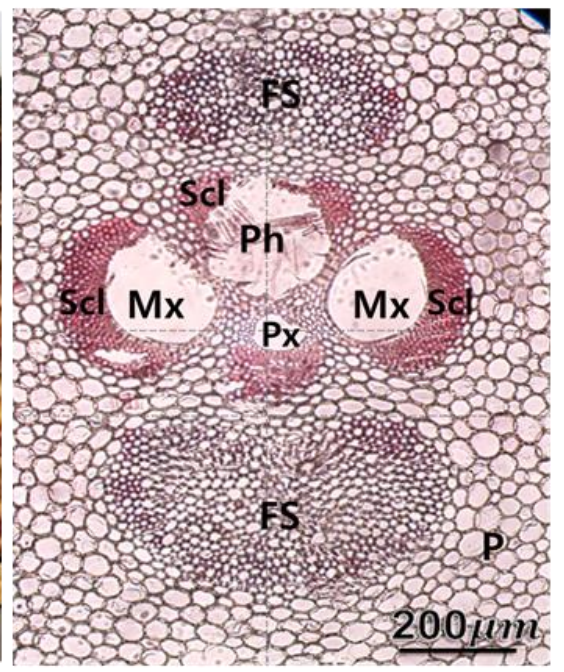

(B)

Fig. 1. General structures on cross section of belangke bamboo (vascular bundle types III and IV): (A) measurements for the frequency and the radial (RD) and tangential (TD) diameters of vascular bundles; (B) fiber sheets (FS), sclerenchyma (Scl), phloem (Ph), metaxylem (Mx), protoxylem $(\mathrm{Px})$, and parenchyma $(\mathrm{P})$

\section{RESULTS AND DISCUSSION}

\section{Vascular Bundle Characteristics}

Figure 1(B) shows the main cellular components of the vascular bundles and parenchymatous tissue in the bamboo culms. Vascular bundles on the cross section of the culm were distributed unevenly and alternately, as shown in Fig. 2. Vascular bundles in the outermost layer were united tightly and tended to enlarge towards the central layer of the culm. That is, the vascular bundles in the outer layer were denser, showing a sparser distribution towards the inner layer. Therefore, the outer layer of bamboo culms showed a darker color than the inner layer.

The frequency of vascular bundles in the belangke bamboo was modeled with the non-linear regression equation shown in Fig. 3. The frequency pattern was not different from other types of bamboo such as Gigantochloa apus (Darwis et al. 2018), Bambusa vulgaris (Darwis and Iswanto 2018), or three Korean bamboo species (Jeon et al. 2018), or from monocotyledonous stems such as oil palm (Darwis et al. 2013). 


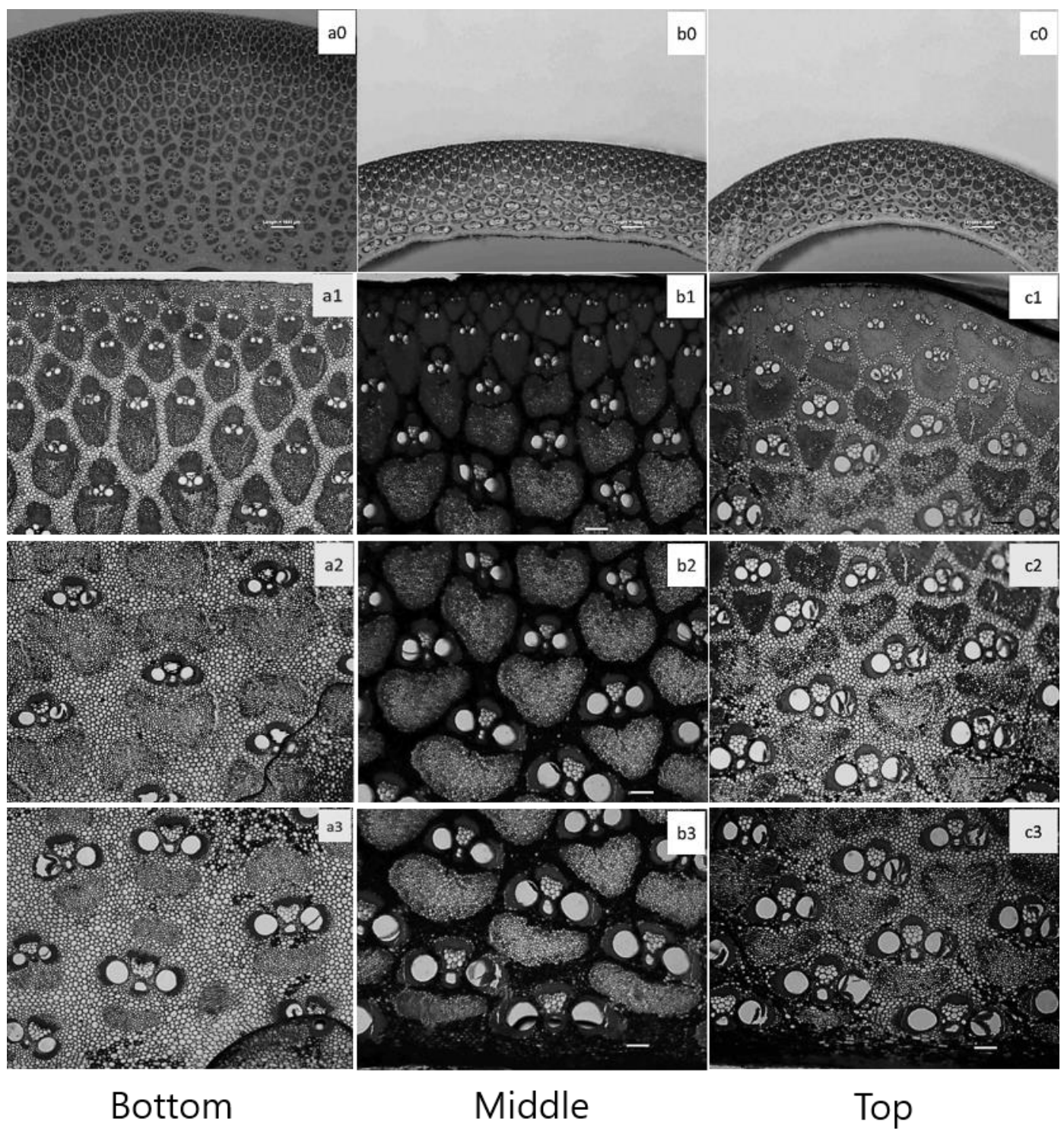

Fig. 2. Optical micrographs of the cross sections of belangke bamboo culm: (a0, b0, and c0) bottom, middle, and top of the bamboo culm; (a1, a2, and a3) outer, central, and inner layers in the bottom culm; (b1, b2, and b3) outer, central, and inner layers in the middle culm; (c1, c2, and c3) outer, central, and inner layers in the top culm. Scale bars in a0, b0, and c0 represent 1000 $\mu \mathrm{m}$; all other scale bars represent $200 \mu \mathrm{m}$.

As shown in Fig. 4, the diameters of vascular bundles in the outer layer were smaller compared to those of the central and inner layers. Vascular bundles in the central layer had greater radial diameters compared to those of the outer layer and the inner layer. The tangential diameters of the vascular bundles increased from the outer layer to the inner layer. In particular, the tangential diameters reached a maximum value at a central part of the cross section of the culm and then kept constant inward. 


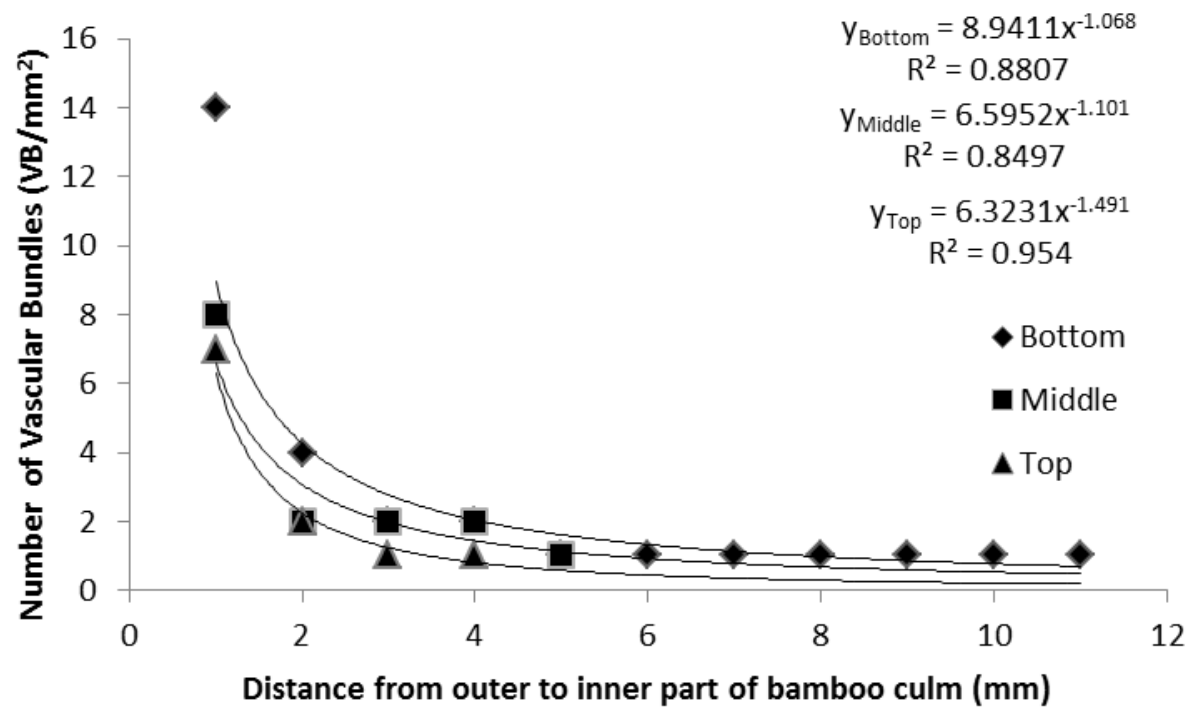

Fig. 3. Frequency of vascular bundles (VB) from outer to inner part of the bamboo culm
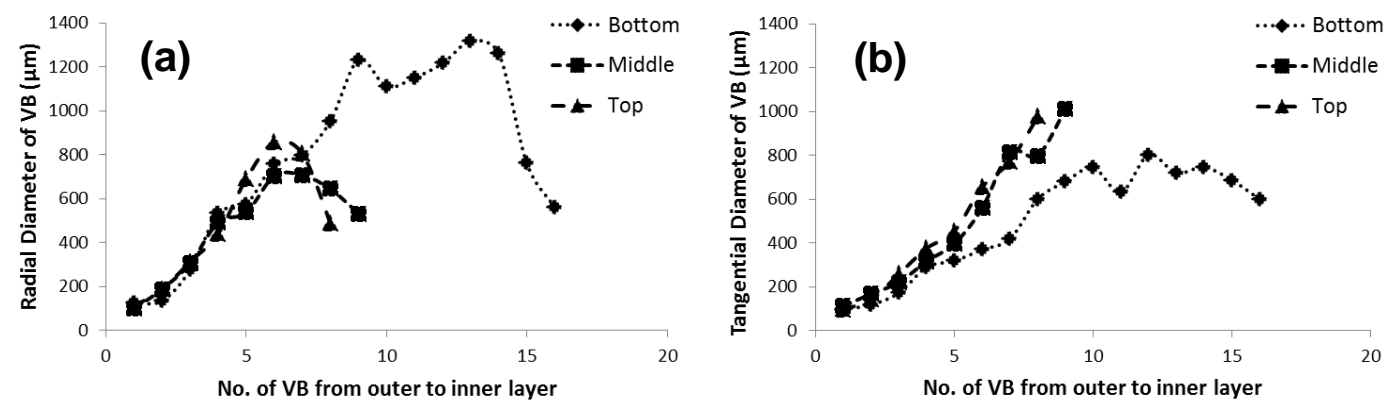

Fig. 4. Variation of (a) radial and (b) tangential diameters of vascular bundles (VB) from outer to inner layers in the bamboo culm

Table 1. Cellular Composition of the Bamboo Culm

\begin{tabular}{|c|c|c|c|}
\hline Vertical Position & Radial Position & $\begin{array}{c}\text { Vascular } \\
\text { Bundles (\%) }\end{array}$ & Parenchyma (\%) \\
\hline \multirow{3}{*}{ Bottom } & Outer & $75.4 \pm 6.7^{\mathrm{AB}}$ & $24.6 \pm 6.67^{A B}$ \\
\hline & Center & $68.8 \pm 7.3^{\mathrm{B}}$ & $31.2 \pm 7.28^{B}$ \\
\hline & Inner & $48.6 \pm 7.5^{\mathrm{A}}$ & $51.4 \pm 7.48^{C}$ \\
\hline \multicolumn{2}{|c|}{ Average } & $64.3 \pm 13.6^{b}$ & $35.7 \pm 13.6^{b}$ \\
\hline \multirow{3}{*}{ Middle } & Outer & $81.7 \pm 4.2^{\mathrm{C}}$ & $18.3 \pm 4.2^{\mathrm{A}}$ \\
\hline & Center & $78.4 \pm 1.6^{C}$ & $21.6 \pm 1.6^{\mathrm{A}}$ \\
\hline & Inner & $70.0 \pm 5.8^{\mathrm{B}}$ & $30.0 \pm 5.8^{\mathrm{B}}$ \\
\hline \multicolumn{2}{|c|}{ Average } & $76.7 \pm 6.4^{b}$ & $23.3 \pm 6.4^{a}$ \\
\hline \multirow{3}{*}{ Top } & Outer & $80.5 \pm 3.4^{C}$ & $19.5 \pm 3.9^{A}$ \\
\hline & Center & $74.7 \pm 2.7^{\mathrm{AB}}$ & $25.3 \pm 2.6^{\mathrm{AB}}$ \\
\hline & Inner & $68.3 \pm 5.5^{\mathrm{B}}$ & $31.7 \pm 5.5^{\mathrm{B}}$ \\
\hline \multicolumn{2}{|c|}{ Average } & $74.5 \pm 6.5^{b}$ & $25.5 \pm 6.4^{a}$ \\
\hline
\end{tabular}

Mean values with different superscript letters in the same column are significantly different at $p<$ 0.05. Statistical groupings (radial and vertical positions) were shown in both capital and lowercase letters, respectively. 
As shown in Table 1, the percentages of vascular bundles and parenchymal tissue in the cross section of the bamboo stem varied significantly in the radial direction. The percentage of vascular bundles decreased from the outer layer to the inner layer and vice versa for the parenchymal tissue. In the vertical direction, the percentage of vascular bundles was the lowest at the bottom part of the stem.

Based on the classification of vascular bundle types (Grosser and Liese 1971), the vascular bundles of the belangke bamboo were identified with both type III and type IV. At the bottom, the typical type of vascular bundle was type IV, which mainly has two fiber bundles on the outside and inside of the central strand. In the middle and top of the culm, the vascular bundles were of type III, which have one bundle of fiber on the inside, as shown in Fig. 2.

\section{Fiber and Metaxylem Characteristics}

Figure 5 shows the fiber and metaxylem vessel morphologies of the belangke bamboo culm. Simple perforation plates and alternate or opposite pitting in vessels were observed. Fibers were straight, with a high slenderness ratio. The dimensions of the components in the culm are summarized in Table 2. In the radial direction at the bottom, middle, and top of the culm, fibers were shortest in the inner layer, and there was no significant difference in fiber length between the outer and central layers.

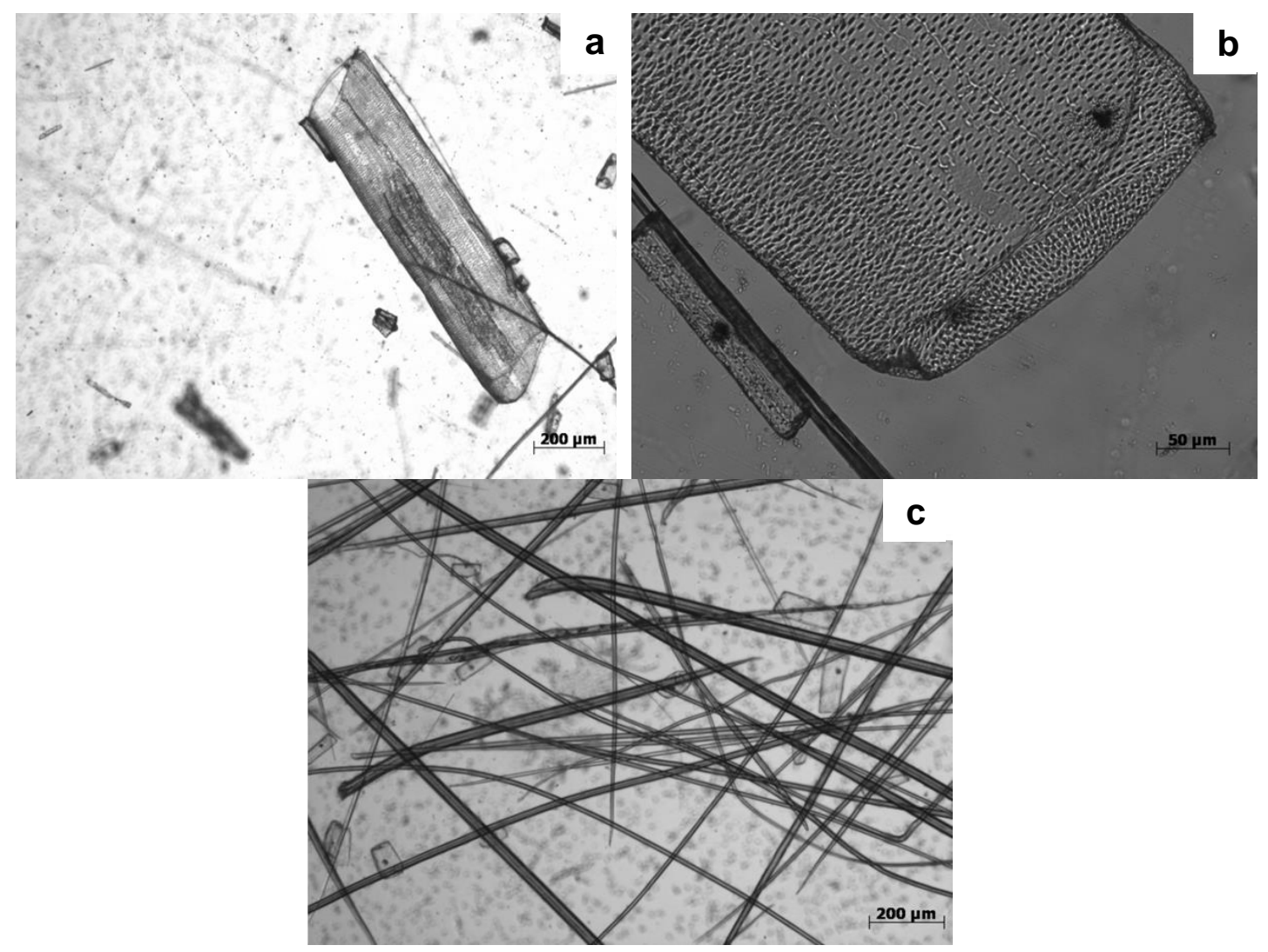

Fig. 5. Morphologies of metaxylem vessels and fibers of belangke bamboo: (a) metaxylem vessel with simple perforation, (b) alternate inter-vessel pits, and (c) thick-walled fibers 
In the vertical direction, the fiber length in the middle and top parts was greater than that at the bottom. There was no significant difference between the middle and top parts. The fiber wall was the thickest in the outer layer of the stem, and it was almost same value in the central and inner parts. Fiber walls were thinnest at the bottom, and there was no difference between the middle and top parts of the culm. For fiber diameter, there was no significant difference in the vertical direction, but there was a significant difference in the radial direction.

In the vertical direction, the vessel length was greatest at the middle and shortest at the top of the culm. In the radial direction, the vessel length seemed to be greatest at the central layer and lowest at the outer layer. The vessel diameter was smallest at the bottom and at the outer part and increased from the outside to the inside of the culm.

Fiber dimensions such as length, diameter, and wall thickness affect the physical and mechanical properties and durability of bamboo (Espiloy 1987). Variations in fiber and metaxylem dimensions in the vertical and radial directions have been found in several bamboos, including Gigantochloa spp.(Mustafa et al. 2011), Bambusa rigida (Huang et al. 2015), Schizostachyum spp. (Sharma et al. 2017), and Phyllostachys spp. (Jeon et al. 2018).

Table 2. Dimensions of Fibers and Metaxylem Vessels in Belangke Bamboo

\begin{tabular}{|c|c|c|c|c|c|c|}
\hline \multirow[b]{2}{*}{$\begin{array}{l}\text { Vertical } \\
\text { Position }\end{array}$} & \multirow[b]{2}{*}{$\begin{array}{c}\text { Radial } \\
\text { Position }\end{array}$} & \multicolumn{3}{|c|}{ Fiber } & \multicolumn{2}{|c|}{ Metaxylem } \\
\hline & & Length $(\mu \mathrm{m})$ & $\begin{array}{l}\text { Diameter } \\
(\mu \mathrm{m})\end{array}$ & $\begin{array}{c}\text { Wall } \\
\text { Thickness } \\
(\mu \mathrm{m})\end{array}$ & Length $(\mu \mathrm{m})$ & $\begin{array}{l}\text { Diameter } \\
\quad(\mu \mathrm{m})\end{array}$ \\
\hline \multirow{3}{*}{ Top } & Inner & $3892 \pm 519^{B C}$ & $23.3 \pm 4.2^{\mathrm{A}}$ & $4.0 \pm 0.8^{\mathrm{AB}}$ & $920 \pm 165^{\mathrm{AB}}$ & $278 \pm 37 E$ \\
\hline & Center & $4522 \pm 660^{D}$ & $28.2 \pm 4.1^{\mathrm{BCD}}$ & $5.4 \pm 1.6^{\mathrm{DE}}$ & $941 \pm 149^{A B}$ & $198 \pm 41^{\mathrm{D}}$ \\
\hline & Outer & $4345 \pm 613^{D}$ & $25.2 \pm 3.6^{\mathrm{AB}}$ & $6.4 \pm 1.2^{F}$ & $837 \pm 210^{A}$ & $109 \pm 33^{A B}$ \\
\hline \multicolumn{2}{|c|}{ Average } & $4253 \pm 651^{b}$ & $25.6 \pm 4.0^{a}$ & $5.3 \pm 1.6^{b}$ & $899 \pm 178^{a}$ & $195 \pm 79^{b}$ \\
\hline \multirow{3}{*}{ Middle } & Inner & $4003 \pm 660^{c}$ & $25.2 \pm 4.5^{\mathrm{AB}}$ & $4.5 \pm 1.3^{\mathrm{ABC}}$ & $1062 \pm 301^{B C}$ & $283 \pm 38^{E}$ \\
\hline & Center & $4552 \pm 664^{D}$ & $30.4 \pm 4.6^{\mathrm{D}}$ & $5.0 \pm 1.0^{\mathrm{CD}}$ & $1077 \pm 232^{\mathrm{BC}}$ & $194 \pm 45^{\mathrm{D}}$ \\
\hline & Outer & $4608 \pm 887^{D}$ & $25.8 \pm 4.1^{\mathrm{ABC}}$ & $5.8 \pm 1.2^{\mathrm{EF}}$ & $913 \pm 196^{\mathrm{AB}}$ & $116 \pm 22^{\mathrm{AB}}$ \\
\hline \multicolumn{2}{|c|}{ Average } & $4388 \pm 786^{b}$ & $27.1 \pm 4.4^{\mathrm{a}}$ & $5.1 \pm 1.3^{b}$ & $1017 \pm 253^{b}$ & $197 \pm 78^{b}$ \\
\hline \multirow{3}{*}{ Bottom } & Inner & $3363 \pm 331^{A}$ & $28.5 \pm 4.7^{C D}$ & $3.9 \pm 0.8^{\mathrm{AB}}$ & $821 \pm 130^{\mathrm{A}}$ & $167 \pm 42^{C}$ \\
\hline & Center & $3663 \pm 362^{\mathrm{AB}}$ & $25.6 \pm 3.6^{\mathrm{ABC}}$ & $3.8 \pm 0.7^{A}$ & $1195 \pm 324^{C}$ & $132 \pm 24^{B}$ \\
\hline & Outer & $3517 \pm 514^{A}$ & $23.5 \pm 2.2^{\mathrm{A}}$ & $4.7 \pm 0.6^{\mathrm{BCD}}$ & $801 \pm 231^{A}$ & $91 \pm 14^{A}$ \\
\hline \multicolumn{2}{|c|}{ Average } & $3515 \pm 424^{a}$ & $25.9 \pm 3.5^{a}$ & $4.2 \pm 0.8^{a}$ & $939 \pm 299^{a b}$ & $130 \pm 42^{a}$ \\
\hline
\end{tabular}

Mean values with different superscript letters in the same column are significantly different at $p<0.05$. Statistical groupings (radial and vertical positions) were shown in both capital and lowercase letters, respectively.

Belangke bamboo has the longest and widest fiber compared to other types of bamboo as shown in Table 3. With the characteristics of these fibers, the belangke bamboo has good prospects for being used as raw material for pulp and cellulose nanofibers. 
Table 3. Comparison of Anatomical Characteristics of Gigantochloa pruriens and Other Bamboo Species

\begin{tabular}{|c|c|c|c|c|c|c|c|}
\hline \multirow{2}{*}{$\begin{array}{c}\text { Bamboo } \\
\text { species } \\
\text { (age) }\end{array}$} & \multirow[b]{2}{*}{$\begin{array}{l}\text { Bamboo } \\
\text { position }\end{array}$} & $\begin{array}{l}\text { Vascular } \\
\text { bundle }\end{array}$ & \multicolumn{3}{|c|}{ Fiber } & \multicolumn{2}{|c|}{ Metaxylem } \\
\hline & & Type & $\begin{array}{l}\text { Length } \\
(\mu \mathrm{m})\end{array}$ & $\begin{array}{c}\text { Diameter } \\
(\mu \mathrm{m})\end{array}$ & $\begin{array}{c}\text { Wall } \\
\text { Thickness } \\
(\mu \mathrm{m})\end{array}$ & $\begin{array}{l}\text { Length } \\
(\mu \mathrm{m})\end{array}$ & $\begin{array}{l}\text { Diameter } \\
\quad(\mu \mathrm{m})\end{array}$ \\
\hline \multirow{3}{*}{$\begin{array}{l}\text { G. pruriens } \\
\text { (2year) }\end{array}$} & Top & III & $\begin{array}{r}4253 \\
\pm 651\end{array}$ & $\begin{array}{l}25.6 \\
\pm 4.0\end{array}$ & $\begin{array}{c}5.3 \\
\pm 1.6\end{array}$ & $\begin{array}{c}899 \\
\pm 178\end{array}$ & $\begin{array}{r}195 \\
\pm 79\end{array}$ \\
\hline & Middle & III & $\begin{array}{r}4388 \\
\pm 786\end{array}$ & $\begin{array}{l}27.1 \\
\pm 4.4\end{array}$ & $\begin{array}{c}5.1 \\
\pm 1.3\end{array}$ & $\begin{array}{r}1017 \\
\pm 253\end{array}$ & $\begin{array}{r}197 \\
\pm 78\end{array}$ \\
\hline & Bottom & IV & $\begin{array}{r}3515 \\
\pm 424\end{array}$ & $\begin{array}{l}25.9 \\
\pm 3.5\end{array}$ & $\begin{array}{c}4.2 \\
\pm 0.8\end{array}$ & $\begin{array}{c}939 \\
\pm 299\end{array}$ & $\begin{array}{r}130 \\
\pm 42\end{array}$ \\
\hline $\begin{array}{l}\text { *G. brang } \\
\text { (3year) }\end{array}$ & - & IV & 1909 & 22.8 & 9.2 & - & - \\
\hline $\begin{array}{l}{ }^{*} \text { G. levis } \\
\text { (3year) }\end{array}$ & - & IV & 2039 & 22.7 & 9.3 & - & - \\
\hline $\begin{array}{c}{ }^{*} \text { G. scortechinii } \\
\text { (3year) }\end{array}$ & - & IV & 1745 & 17.2 & 4.3 & - & - \\
\hline $\begin{array}{l}\text { *G. wrayi } \\
\text { (3year) }\end{array}$ & - & IV & 1798 & 17.9 & 7.0 & - & - \\
\hline \multirow{3}{*}{$\begin{array}{l}{ }^{* *} B \text {. rigida } \\
\text { (3year) }\end{array}$} & Top & \multirow{3}{*}{ III } & 1617 & 2.6 & 10.2 & - & 97 \\
\hline & Middle & & 1848 & 3.2 & 10.9 & - & 114 \\
\hline & Bottom & & 1809 & 4.6 & 10.5 & - & 127 \\
\hline \multirow{3}{*}{$\begin{array}{l}\text { ** S. manii } \\
\text { (3year) }\end{array}$} & Top & \multirow{3}{*}{$\mathrm{I} \sim \mathrm{III}$} & 2256 & 14.1 & 5.3 & 1362 & 106 \\
\hline & Middle & & 2677 & 14.1 & 5.0 & 1315 & 106 \\
\hline & Bottom & & 2733 & 16.2 & 5.4 & 1412 & 112 \\
\hline \multirow{3}{*}{$\begin{array}{l}{ }^{* * *} \text { S. munroi } \\
\text { (3year) }\end{array}$} & Top & \multirow{3}{*}{$\mathrm{I} \sim \mathrm{III}$} & 2588 & 18.7 & 7.4 & 1220 & 95 \\
\hline & Middle & & 3013 & 21.4 & 8.3 & 1335 & 76 \\
\hline & Bottom & & 3027 & 22.5 & 8.6 & 1326 & 56 \\
\hline
\end{tabular}

Notes: * Mustafa et al. (2011), ${ }^{\star *}$ Huang et al. (2015), ${ }^{\star \star \star}$ Sharma et al. (2017)

\section{CONCLUSIONS}

1. Vascular bundles on the cross section of the belangke bamboo culm were distributed unevenly. Most vascular bundles were classified as type IV at the bottom and as type III in the middle and top parts.

2. The vascular bundles were smaller and denser in the outer layer and showed a sparser distribution inward. The frequency of vascular bundles decreased toward the inner layer and increased upwards of the stem.

3. Fiber length in the middle and top parts was greater than that at the bottom. The fibers were shortest in the inner layer, and there was no significant difference in fiber length between the outer and central layers. The fiber wall was thickest in the outer layer and thinnest at the bottom of the culm.

4. In the vertical direction, vessel length was greatest at the middle part and the smallest at the top. In the radial direction, vessel length was greatest in the central layer and smallest in the outer layer. The vessel diameter was the smallest at the bottom and in the outer layer and increased toward inner layer of the culm. 


\section{ACKNOWLEDGMENTS}

The authors would like to express their sincere thanks to the Directorate General of Higher Education, Ministry of Research, Technology, and Higher Education, Republic of Indonesia, for research support funding through the grant of Penelitian Dasar Unggulan Perguruan Tinggi (PDUPT) (No.11/E1/KP.PTNBH/2019). This study was also supported by the Basic Science Research Program through the National Research Foundation of Korea (NRF), funded by the Ministry of Education (No. NRF-2016R1D1A1B01008339), and the Science and Technology Support Program through the NRF, funded by the Ministry of Science and ICT (MSIT) (No. NRF-2019K1A3A9A01000018).

\section{REFERENCES CITED}

Darwis, A., and Iswanto, A. H. (2018). "Morphological characteristics of Bambusa vulgaris and the distribution and shape of vascular bundles therein," Journal of the Korean Wood Science and Technology 46(4), 315-322 DOI: 10.5658/wood.2018.46.4.315

Darwis, A., Nurrochmat, D. R., Massijaya, M. Y., Nugroho, N., Alamsyah, E. M., Bahtiar, E. T., and Safe i, R. (2013). "Vascular bundle distribution effect on density and mechanical properties of oil palm trunk," Asian Journal of Plant Sciences 12(5), 208-213. DOI: 10.3923/ajps.2013.208.213

Darwis, A., Sumardi, I., Suhaya, Y., and Sunarya, S. (2018). "Characteristic of vascular bundles and morphology of Gigantochloa apus (J. A. and J. H. Schulltes) Kurz culm," Asian Journal of Plant Sciences 17(3), 129-133. DOI: 10.3923/ajps.2018.129.133

Dransfield, S., and Widjaja, E. A. (eds.) (1995). Plant Resources of South-East Asia No 7: Bamboos, Backhuys Publishers, Leiden, The Netherlands.

Espiloy, Z. B. (1987). "Physico-mechanical properties and anatomical relationship of some Philippine bamboos," in: Proceedings of the International Bamboo Workshop, Hangzhou, China, pp. 257-264.

Franklin, G. L. (1945). "Preparation of thin sections of synthetic resins and wood-resin composites, and a new macerating method for wood," Nature 155(3924), 51.

Grosser, D., and Liese, W. (1971). "On the anatomy of Asian bamboos, with special reference to their vascular bundles," Wood Science and Technology 5, 290-312. DOI: 10.1007/BF00365061

Huang, X.-Y., Qi, J.-Q., Xie, J.-L., Hao, J.-F., Qin, B.-D., and Chen, S.-M. (2015). "Variation in anatomical characteristics of bamboo, Bambusa rigida," Sains Malaysiana 44(1), 17-23. DOI: 10.17576/jsm-2015-4401-03

Jeon, W.-S., Kim, Y.-K., Lee, J.-A., Kim, A.-R., Darsan, B., Chung, W.-Y., and Kim, N.H. (2018). "Anatomical characteristics of three Korean bamboo species," Journal of the Korean Wood Science and Technology 46(1), 29-37. DOI: 10.5658/wood.2018.46.1.29

Liese, W. (1987a). "Anatomy and properties of bamboo," in: Proceedings of the International Bamboo Workshop, Hangzhou, China, pp. 196-208.

Liese, W. (1987b). "Research on bamboo," Wood Science and Technology 21, 189-209. DOI: 10.1007/BF00351391 
Liese, W. (1998). The Anatomy of Bamboo Culms (Technical Report 18), International Network for Bamboo and Rattan, Beijing, China.

Mustafa, M. T., Wahab, R., Sudin, M., Sulaiman, O., Kamal, N. A. M., and Khalid, I. (2011). "Anatomical and microstructures features of tropical bamboo Gigantochloa brang, G. levis, G. scotechinii and G. wrayi," International Journal of Forest, Soil and Erosion 1(1), 25-35.

Sharma, M., Sharma, C. L., and Laishram, D. (2017). "Variation in anatomical and physical properties of some Schizostachyum species of Manipur, India," Journal of the Indian Academy of Wood Science 14(1), 79-90. DOI: 10.1007/s13196-017-0191-0

Widjaja, E. A. (1987). "A revision of Malesian Gigantochloa (Poaceae Bambusoideae)," Reinwardtia 10(3), 291-380.

Widjaja, E. A. (2001). Identity Kits for the Bamboo Species in Java, Research and Development Center for Biology, Indonesian Institute of Sciences (LIPI), Bogor, Indonesia.

Zakikhani, P., Zahari, R., Sultan, M. T. H., Majid, D. L. (2017). "Morphological, mechanical, and physical properties of four bamboo species," BioResources 12(2), 2479-2495.

Article submitted: May 25, 2020; Peer review completed: June 21, 2020; Revised version received and accepted: July 2, 2020; Published: July 9, 2020.

DOI: 10.15376/biores.15.3.6617-6626 